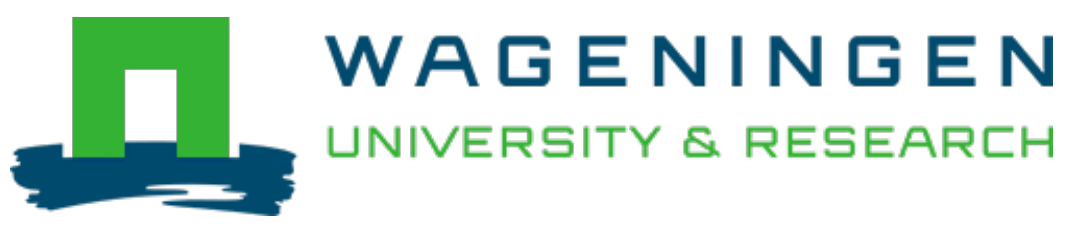

\title{
Toxicological, nutritional and microbiological evaluation of tempeh fermentation with Rhizopus oligosporus of bitter and sweet apricot seeds
}

\author{
International Journal of Food Microbiology \\ Tunçel, G.; Nout, M.J.R.; Brimer, L.; Göktan, D. \\ https://doi.org/10.1016/0168-1605(90)90027-3
}

This publication is made publicly available in the institutional repository of Wageningen University and Research, under the terms of article $25 \mathrm{fa}$ of the Dutch Copyright Act, also known as the Amendment Taverne. This has been done with explicit consent by the author.

Article 25 fa states that the author of a short scientific work funded either wholly or partially by Dutch public funds is entitled to make that work publicly available for no consideration following a reasonable period of time after the work was first published, provided that clear reference is made to the source of the first publication of the work.

This publication is distributed under The Association of Universities in the Netherlands (VSNU) 'Article $25 \mathrm{fa}$ implementation' project. In this project research outputs of researchers employed by Dutch Universities that comply with the legal requirements of Article $25 \mathrm{fa}$ of the Dutch Copyright Act are distributed online and free of cost or other barriers in institutional repositories. Research outputs are distributed six months after their first online publication in the original published version and with proper attribution to the source of the original publication.

You are permitted to download and use the publication for personal purposes. All rights remain with the author(s) and / or copyright owner(s) of this work. Any use of the publication or parts of it other than authorised under article $25 \mathrm{fa}$ of the Dutch Copyright act is prohibited. Wageningen University \& Research and the author(s) of this publication shall not be held responsible or liable for any damages resulting from your (re)use of this publication.

For questions regarding the public availability of this publication please contact openscience.library@wur.nl 


\title{
Toxicological, nutritional and microbiological evaluation of tempe fermentation with Rhizopus oligosporus of bitter and sweet apricot seeds
}

\author{
G. Tunçel ${ }^{1}$, M.J.R. Nout ${ }^{2}$, L. Brimer ${ }^{3}$ and D. Göktan ${ }^{1}$ \\ 'Food Engineering Department, Ege University, Izmir, Turkey, ${ }^{2}$ Department of Food Science, Agricultural \\ University, Wageningen, The Netherlands, and ${ }^{3}$ Department of Pharmacology and Toxicology, Royal \\ Veterinary and Agricultural University, Frederiksberg, Denmark
}

(Received 16 March 1990; accepted 30 July 1990)

Bitter and sweet apricot seeds are by-products of the apricot processing industry. Bitter seeds, in particular, contain toxic levels of the cyanogenic substance amygdalin. Tempe was made from both kinds of seeds. The bitter seeds contain antimicrobial substances which must be removed by leaching and boiling prior to tempe fermentation. Apricot seed tempe had an agreeable taste. It contained approx. $21 \%$ $(\mathrm{w} / \mathrm{w})$ crude protein, $52 \%(\mathrm{w} / \mathrm{w})$ crude fat, $1.5 \%(\mathrm{w} / \mathrm{w})$ crude fibre and $25.5 \%(\mathrm{w} / \mathrm{w})$ carbohydrates based on dry matter. The extent of biological acidification during soaking prior to fungal inoculation was inadequate to prevent growth of Bacillus cereus, and requires further optimisation. Bitter seeds were detoxified by the tempe process (approx. $70 \%$ of total cyanide was removed). However, additional improvement of the detoxification process is required to obtain a completely safe product.

Key words: Apricot seeds; Amygdalin; Bacillus cereus; Tempe; Detoxification; Fungi; Rhizopus oligosporus

\section{Introduction}

Apricot (Prunus armeniaca) is the most delicious stone fruit consumed during the summer season in Turkey. It is used fresh, or processed as apricot juice, nectar, jam and dried fruit. The amount of apricot seeds remaining after processing is quite large. These can be utilised to produce edible oil and bitter almond oil. Apricot seeds contain a high level of protein which can be used as a food ingredient. However, they also contain amygdalin, a poisonous cyanogenic glucoside compound which may be lethal to humans. Amygdalin was first identified in bitter almonds and is also present in the seeds of other fruits (Montgomery, 1969). The toxicity of this compound is due to the liberation of $\mathrm{HCN}$, a potent inhibitor of cellular respiration and a compound able to interfere with both amino acid metabolism (Aitken and Braitman, 1989) and neurotransmission in the central nervous system

Correspondence address: M.J.R. Nout, Department of Food Science, Agricultural University, Bomenweg 2, 6703 HD Wageningen, The Netherlands. 
(Yamamoto, 1989). With regard to amygdalin, bitter almonds have caused accidental deaths (Blyth and Blyth, 1920). Accidental poisoning has occasionally followed the ingestion of peach kernels (Montgomery, 1969), Kalabey apricot (McTaggart, 1936) and choke cherries (Pijoan, 1942).

When the seeds are macerated in water, hydrolysis of amygdalin occurs. Most of the $\mathrm{HCN}$ formed evaporates during boiling. If the cooking utensil is covered with a lid, condensation occurs and the cooking water may become heavily contaminated (Montgomery, 1969).

In this research, bitter and sweet apricot seeds were used to produce tempe, aimed at obtaining a nutritious and detoxified product. Tempe is usually made of soyabeans fermented with Rhizopus oligosporus, although it can be made of other grains (Ko and Hesseltine, 1979).

\section{Materials and Methods}

\section{Materials}

Bitter and sweet apricot seeds were obtained from Izmir, Turkey. Rhizopus oligosporus NRRL 5905 was grown and maintained on malt extract agar (MEA, Oxoid CM 59) slants. Incubation was at $30^{\circ} \mathrm{C}$ for 1 week, and grown cultures were stored at $5^{\circ} \mathrm{C}$.

\section{Methods}

\section{Preparation of tempe}

Tempe was prepared according to the procedure described by Tunçel et al. (1989). Apricot seeds were ground to grits using a household blender (Moulinex, France). The particle size distribution was determined using ASTM E 11-70 test sieves No. 4, 10 and 18 (Retsch, Haan, F.R.G.) and was as follows: $25 \%<1.10$ $\mathrm{mm} ; 17.8 \% 1.00-2.00 \mathrm{~mm} ; 35 \% 2.00-4.75 \mathrm{~mm} ; 22.2 \%>4.75 \mathrm{~mm}$. Two types of soaking were compared: (i) a neutral soak at $4^{\circ} \mathrm{C}$ for $18 \mathrm{~h}$ avoiding biological acidification, and (ii) a fermentative soak at $20^{\circ} \mathrm{C}$ for $18 \mathrm{~h}$ using the principle of accelerated lactic fermentation with inoculum rate $10 \%(\mathrm{v} / \mathrm{v}$ ) (Nout et al., 1987b). Prior to inoculation the grits were boiled in water in an open vessel for $30 \mathrm{~min}$, drained and cooled.

\section{Microbiological analysis}

Sample preparation, enumeration of lactic acid bacteria, Enterobacteriaceae, Bacillus cereus, Staphylococcus aureus, and reporting of counts was described previously (Nout et al., 1987a; Tunçel et al., 1989). All samples were analysed in duplicate and their mean values were reported.

\section{Chemical analysis}

Crude protein, crude fat and crude fibre contents were determined by AOAC methods nr. 27007, 27006, and 7054, respectively (Horwitz, 1975). Carbohydrate 
content was determined by difference. Total cyanide content was determined as follows: sample aliquots of $7.00 \mathrm{~g}$ were extracted thrice with portions of $70 \mathrm{ml}$ boiling 70\% ethanol (1 min in a Sorvall Omnimixer (model 17106, Dupont Co., Newton, USA) at full speed each time), followed by immediate filtration by suction through a Whatman ${ }^{\mathbb{B}}$ filterpaper qualitative No.2 (Whatman Ltd., Springfield Mill, Maidstone, Kent, U.K.) into an ice-cooled container. The pooled extracts were made up to $250 \mathrm{ml}$ with $70 \%$ ethanol, and the resulting solution was analysed for the presence of amygdalin, prunasin, mandelonitrile (cyanohydrin) by a quantitative 'spot' test (Brimer and Mølgaard, 1986) and thin layer chromatography-densitometry (Brimer et al., 1983). All samples were analysed in duplicate and their mean values reported. All trials had two replications. The limit of quantification (which is higher than the limit of detection by a factor $2-3$ ) is around $0.7-0.8 \mathrm{nmol} \mathrm{HCN} / \mathrm{mg}$ dry weight.

\section{Results and Discussion}

Bitter and sweet apricot seeds were used in this study. Using the tempe process as applicable to soyabeans, whole sweet seeds gave an acceptable tempe. In contrast, whole bitter seeds did not allow growth of $R$. oligosporus. We found that only grits (53\% w/w having particle size of $1.0-4.8 \mathrm{~mm}$ ) of bitter seeds enabled good fungal growth, on condition that boiling was prolonged $(30 \mathrm{~min})$ and took place in an open vessel (data not shown).

Earlier studies (Nout et al, 1987a, b) on tempe fermentation showed that microbiological safety, shelf-life and acceptability of finished tempe was improved by lactic fermentation during the soaking of raw material prior to fungal fermentation. In order to increase the speed and reliability of this fermentation, a system of accelerated natural lactic fermentation was developed, which can be applied to a variety of raw materials of plant origin (Nout et al., 1989).

As expected, particle size influenced mass transfer during soaking and boiling. Leaching of dry matter into the soaking water was highest $(28 \%(\mathrm{w} / \mathrm{w})$ after $24 \mathrm{~h}$ at $20^{\circ} \mathrm{C}$ ) with grits (data not shown) and consequently, more fermentable matter was available for accelerated lactic fermentation. However, Fig. 1 shows that this does not influence the speed of acidification of the soak water. The $\mathrm{pH}$ differences in various seed particle sizes must therefore be caused by the diffusion rate of acids into the seed material. This is clear from Fig. 1 showing that the $\mathrm{pH}$ values of soak water and dry matter come closest in soaked grits during biological acidification.

Although leaching losses were highest when using grits, the latter were chosen for tempe making because of their relative freedom of inhibitors and their good acidification.

In Table $\mathbf{I}$ it is shown that amygdalin was the main cyanogenic constituent in most samples. On the one hand, the cyanide content in raw sweet seeds is low, and the tempe process causes only a slight decrease. On the other hand, in raw bitter seeds soaking and boiling have a significant detoxifying effect. Soaking with lactic fermentation results in the lowest content of cyanogenic constituents in tempe from bitter seed grits. 


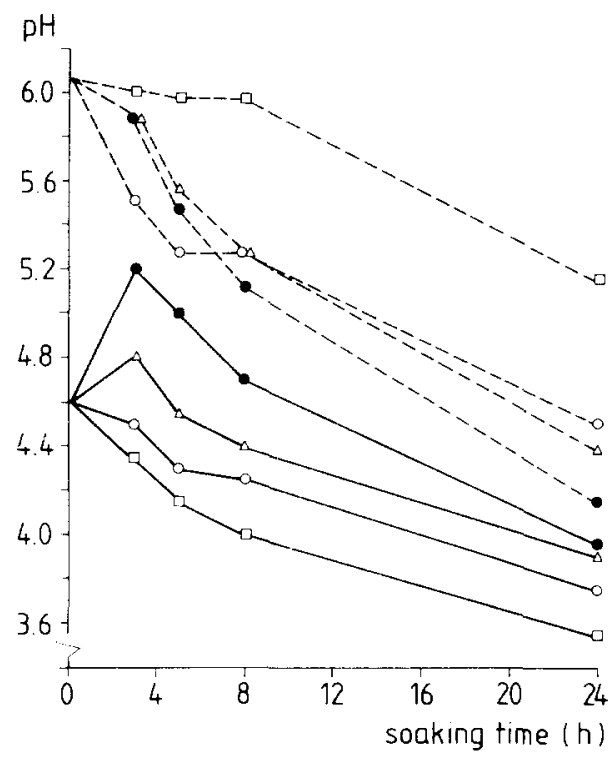

Fig. 1. Effect of particle size of sweet apricot seeds on $\mathrm{pH}$ of seeds and soak water during lactic fermentation. $\square$ whole seeds; $\bigcirc$ halved seeds; $\Delta$ quartered seeds; $\bullet$ grits (particle size distribution: $25 \%<1.00 \mathrm{~mm} ; 17.8 \%$ of $1.00-2.00 \mathrm{~mm} ; 35 \%$ of $2.00-4.80 \mathrm{~mm} ; 22.2 \%>4.80 \mathrm{~mm}$ ) $\ldots .$. seeds; water.

According to Poulton (1988) the cyanogenic disaccharide glycoside amygdalin present in seeds of many members of the plant families Rosaceae, Malaceae, and Amygdalaceae (to which the genus Prunus belongs), is degraded through a sequential mechanism. Thus two distinct $\beta$-glycosidases, namely amygdalin hydrolase and prunasin hydrolase, have been completely resolved in extracts from e.g. Prunus

\section{TABLE I}

Total cyanide content (nmol HCN/mg dry weight) of bitter and sweet apricot seed grits when processed into tempe after soaking with or without lactic fermentation

\begin{tabular}{|c|c|c|c|c|}
\hline & \multicolumn{2}{|l|}{ Bitter seed grits } & \multicolumn{2}{|l|}{ Sweet seed grits } \\
\hline & Non-fermented & $\begin{array}{l}\text { Lactic } \\
\text { fermented }\end{array}$ & Non-fermented & $\begin{array}{l}\text { Lactic } \\
\text { fermented }\end{array}$ \\
\hline Raw & $52 \pm 2.4^{1}$ & $52 \pm 2.4^{1}$ & $2.44 \pm 0.34^{2}$ & $2.44 \pm 0.34^{2}$ \\
\hline Soaked & $40.6 \pm 2.5^{3}$ & $15.5 \pm 0.8^{3}$ & $1.6 \pm 0.06$ & $3.3 \pm 0.8^{2}$ \\
\hline Boiled & $14.8 \pm 0.6^{4}$ & $16.9 \pm 0.5^{4}$ & & \\
\hline Tempe & $15.8 \pm 0.9^{4}$ & $10.0 \pm 0.3^{4}$ & $2.0 \pm 0.04^{4}$ & -5 \\
\hline
\end{tabular}

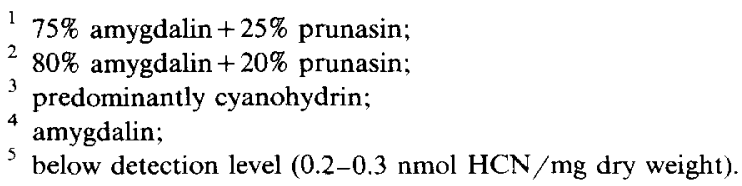


serotina Ehrh., while clear evidence for a sequential mechanism involving prunasin as an intermediate product has been obtained for other Prunus spp. The $\alpha$-hydroxynitriles (in this case mandelonitrile) arising from the catabolism of the cyanogenic glycoside, are then further degraded to $\mathrm{HCN}$ and an aldehyde or ketone by an $\alpha$-hydroxynitrile lyase. In the case of Prunus spp. all the "mandelonitrile lyases" isolated have had the flavin coenzyme (Flavin adenine dinucleotide) FAD bound close to the catalytic site (Poulton, 1988).

These plant enzymes are extracellular and gain access to the glucoside after physical disruption of the cell. They will act at about $20-40^{\circ} \mathrm{C}$ and are readily destroyed by heat. Autohydrolysis is enhanced if the plant is soaked in water after crushing. Bruising without soaking will lead to slow release of $\mathrm{HCN}$. The boiling point of $\mathrm{HCN}$ is $26^{\circ} \mathrm{C}$; storage in hot humid conditions therefore leads to gradual loss of HCN (Montgomery, 1969). The rate of $\mathrm{HCN}$ release for a given material and $\mathrm{pH}$ depends on the physical conditions. Viehoever (1940) found that the HCN yield from Phaseolus lunatus was highest after $45 \mathrm{~min}$ if the bean was soaked in water at $37^{\circ} \mathrm{C}$ after crushing. Winkler (1951) considered that the yield was greater if the crushed bean was soaked for $24 \mathrm{~h}$ at room temperature. In the case of linseed cake used for cattle feed, Auld (1912) found that half of the available HCN might be released after a 15-min soaking in the cold. Linseed cake contains the cyanogenic constituents linustatin and neolinustatin (Smith et al., 1980) and the enzymes linamarase and linustatinase (Fan and Conn, 1987).

With microorganisms involved, additional degradative enzymes including e.g. biglycosidase, catalysing the step from amygdalin to mandelonitrile directly, may contribute to the breakdown of the amygdalin. This is why we analysed for the presence of all three potential cyanogenic compounds in addition to $\mathrm{HCN} / \mathrm{CN}^{-}$. The presence of residual cyanogenic constituents might be caused by pools not reached by the enzymes during the two fermentation steps of the tempe process, or by chemical stabilisation of e.g. $\mathrm{HCN} / \mathrm{CN}^{-}$through reaction with, for example, ketones/aldehydes to form new cyanohydrins (Zitnak, 1973).

The minimum lethal dose for humans of $\mathrm{HCN}$ taken orally has been estimated at between $0.5 \mathrm{mg}$ and $3.5 \mathrm{mg} / \mathrm{kg}$ body weight (Montgomery, 1969). Our study showed that $0.184 \mathrm{mg} \mathrm{HCN}$ could be released from $1 \mathrm{~g}$ (fresh weight) of tempe as produced from bitter seeds and further reduction of cyanide levels will still be desirable, since chronic $\mathrm{HCN}$ intoxications may result from intake of sub-acute doses over a prolonged period (Rosling, 1986). This might be achieved by fermentative soaking at higher temperatures (e.g. $30-35^{\circ} \mathrm{C}$ ) and/or prolonged fungal fermentation (i.e. 72 $\mathrm{h}$ instead of $48 \mathrm{~h}$ ).

In soyabean tempe of poor quality, Staphylococcus aureus and Bacillus cereus may occur in numbers which may cause food intoxication (Samson et al., 1987). It was shown, however, that in tempe made from previously acidified soyabeans, staphylococcal growth and enterotoxin formation was strongly reduced (Nout et al., 1988). Also, the growth of Bacillus cereus in tempe was inhibited when well-acidified $(\mathrm{pH} \leq 4.4)$ soyabeans were used (Nout et al., 1987a).

Table II summarises the microbiological analyses of raw and soaked apricot seeds, and tempe. The results show that sweet seeds acidify better during the 
TABLE II

$\mathrm{pH}$ and microbiological composition of bitter and sweet apricot seed grits during tempe production (log $\mathrm{cfu} / \mathrm{g}$ )

\begin{tabular}{|c|c|c|c|c|}
\hline & $\mathrm{pH}$ & $\begin{array}{l}\text { Lactic } \\
\text { acid } \\
\text { bacteria }\end{array}$ & $\begin{array}{l}\text { Entero- } \\
\text { bacteriaceae }\end{array}$ & $\begin{array}{l}\text { Bacillus } \\
\text { cereus }\end{array}$ \\
\hline \multicolumn{5}{|l|}{ Bitter seed grits } \\
\hline Raw & 6.0 & & & \\
\hline Soaked & & & & \\
\hline $\begin{array}{l}\text { non-fermented } \\
\text { Soaked }\end{array}$ & 6.2 & 2.30 & 2.00 & 2.95 \\
\hline fermented & 5.7 & 7.11 & $<1.70$ & 5.08 \\
\hline $\begin{array}{l}\text { Tempe from } \\
\text { non-fermented soaked grits }\end{array}$ & 6.2 & 8.23 & 6.30 & 8.28 \\
\hline Tempe from & 62 & 660 & 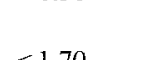 & \\
\hline the & & & & \\
\hline \multicolumn{5}{|l|}{ Sweet seed grits } \\
\hline Raw & 5.8 & & & \\
\hline $\begin{array}{l}\text { Soaked } \\
\text { non-fermented } \\
\text { Soaked }\end{array}$ & 5.9 & 2.30 & 1.48 & 3.28 \\
\hline $\begin{array}{l}\text { fermented } \\
\text { Tempe from }\end{array}$ & 4.4 & 8.32 & $<1.70$ & 8.34 \\
\hline $\begin{array}{l}\text { non-fermented soaked grits } \\
\text { Tempe from }\end{array}$ & 6.1 & 6.90 & 5.72 & 6.68 \\
\hline fermented soaked grits & 6.1 & 6.76 & 5.28 & 7.52 \\
\hline
\end{tabular}

soaking operation. It is probable that the mould inhibitors in bitter seeds also affect lactic acid bacteria. A boiling step prior to soaking fermentation might help to reduce the inhibitive effect in bitter seeds. Bacillus cereus, naturally occurring in the raw material, were able to grow very well even in the fermented soaked sweet seed grits with $\mathrm{pH}$ 4.4. This indicates that further optimisation of the soak fermentation is required.

In all samples of fermented apricot seeds, Staphylococcus aureus was below detection level $(\log \mathrm{cfu} / \mathrm{g}<2.70)$.

Based on dry weight, raw bitter grits, tempe from non-fermented soaked bitter grits, tempe from fermented soaked bitter grits, raw sweet grits, tempe from non-fermented soaked sweet grits, and tempe from fermented soaked sweet grits contained 21.6, 20.2, 21.2, 23.9, 20.7 and $22.3 \%$ crude protein; 42.5, 50.1, 51.5, 34.1, 48.4 and $56.9 \%$ crude fat; $2.5,1.8,1.3,2.7,1.6$ and $1.1 \%$ crude fibre and $33.4,27.9$, 26.0, 39.3, 29.3 and $19.7 \%$ carbohydrate, respectively. These results are similar to those of Abd El-Aal et al. (1986) and Kapoor et al. (1987), with slight differences which are probably due to interspecies variation. The increased crude fat content in tempe is not caused by fat synthesis, but by a shift in dry matter composition due to decreased carbohydrate content. Leaching and fermentation during soaking and fungal growth are probably responsible for this reduction. 
Although apricot seed tempe contains less crude protein than soyabean tempe (Vaidehi et al., 1985) apricot seeds are an attractive raw material because they are cheaper than soyabeans. In addition, apricot seed tempe had a more attractive taste than soyabean tempe according to Turkish and Dutch taste evaluations (unpublished results).

According to Kapoor et al. (1987), the protein content of apricot seeds ranged from about $20-45 \%$ depending on the variety. Thus, product value could be increased by selecting high-protein apricot seed varieties for tempe processing. Another potential use of apricot seeds is the manufacture of detoxified flour or protein isolate (Abd El-Aal et al., 1986).

\section{Acknowledgement}

The authors thank Prof. F.M. Rombouts, Department of Food Science, Agricultural University Wageningen, for his constructive criticism during this investigation.

\section{References}

Abd El-Aal, M.H., Hamza, M.A. and Rahma, E.H. (1986) In vitro digestibility, physico-chemical and functional properties of apricot kernel proteins. Food Chem. 19, 197-211.

Aitken, P.G. and Braitman, D.J. (1989) The effect of cyanide on neural synaptic function in hippocampal slices. Neurotoxicology 10, 239-248.

Auld, S.J.M. (1912) The formation of prussic acid from linseed cake and other feeding stuffs. J. Board Agric. 19, 446-460.

Blyth, A.W. and Blyth, M.W. (1920) Poisons, 5th edn., pp. 215--223. Griffiths, London.

Brimer, L., Christensen. S.B., Melgaard, P. and Nartey, F. (1983) Determination of cyanogenic compounds by thin layer chromatography. 1. A densitometric method for quantification of cyanogenic glycosides, employing enzyme preparations (beta-glucuronidase) from Helix pomatia and picrate-impregnated ion-exchange sheets. J. Agric. Food Chem. 31, 789-793.

Brimer, L. and Mølgaard, P. (1986) Simple densitometric method for estimation of cyanogenic glycosides and cyanohydrins under field conditions. Biochem. Syst. Ecol. 14, 97-103.

Fan, T.W.M. and Conn, E.E. (1987) Isolation and characterisation of two cyanogenic beta-glucosidases from flax seeds. Arch. Biochem. Biophys. 243, 361-373.

Horwitz, W. (1975) Official Methods of Analysis of the Association of Official Analytical Chemists. 12th edn. Washington DC, A.O.A.C.

Kapoor, N., Bedi, K.L. and Bhatia, A.K. (1987) Chemical composition of different varieties of apricots and their kernels grown in Ladakh Region. J. Food Sci. Technol. 24, 141-143.

Ko, S.D. and Hesseltine, C.W. (1979) Tempe and related foods. pp. 115-140. In: A.H. Rose (Ed.), Economic Microbiology. Vol. 4, Microbial Biomass. Academic Press, London.

McTaggart, C.M. (1936) Hydrocyanic poisoning from nuts. Br. Med. J. 2, 100.

Montgomery, R.D. (1969) Cyanogens. In: I.E. Liener, (Ed.), Toxic Constituents of Plant Foodstuffs. pp. 143-157. Academic Press, London.

Nout, M.J.R., Beernink, G. and Bonants-van Laarhoven, T.M.G. (1987a) Growth of Bacillus cereus in soya-bean tempeh. Int. J. Food Microbiol. 4, 239-301.

Nout, M.J.R., De Dreu, M.A., Zuurbier, A.M. and Bonants-van Laarhoven, T.M.G. (1987b) Ecology of controlled soyabean acidification for tempe manufacture. Food Microbiol. 4, 165-172.

Nout, M.J.R. , Notermans, S. and Rombouts, F.M. (1988) Effect of environmental conditions during soya-bean fermentation on the growth of Staphylococcus aureus and production and thermal stability of enterotoxins A and B. Int. J. Food Microbiol. 8, 299-309. 
Nout, M.J.R., Rombouts, F.M. and Hautvast, G.J. (1989) Accelerated natural lactic fermentation of infant food formulations. United Nations University Food and Nutrition Bulletin 11, 65-73.

Pijoan, M. (1942) Cyanide poisoning from choke cherry seed. Am. J. Med. Sci. 204, 550-553.

Poulton, J.E. (1988) Localization and catabolism of cyanogenic glycosides. In: D. Evered and S. Harnett (Eds.), Cyanide Compounds in Biology. John Wiley \& Sons, Chichester. pp. 67-91.

Rosling, H. (1986) Cassava, cyanide, and epidemic spastic paraparesis: A study in Mozambique on dietary cyanide exposure. Acta Universitatis Upsalensis (Comprehensive Summaries of Uppsala). Dissertation from the Faculty of Medicine.

Samson, R.A. , Van Kooij, J.A. and De Boer, E. (1987) A survey of the microbiological quality of commercial tempeh in the Netherlands. J. Food Protect. 50, 92-94.

Smith, C.R. Jr., Weisleder, D., Palmer, I.S. and Palmer, O.E. (1980) Linustatin and neolinustatin: cyanogenic glycosides in linseed meal that protect against selenium toxicity. J. Org. Chem. 45 , $507-510$.

Tunçel, G., Nout, M.J.R. and Rombouts, F.M. (1989) Effect of acidification on the microbiological composition and performance of tempe starter. Food Microbiol. 6, 37-43.

Vaidehi, M.P., Annapurna, M.L. and Vishwanath, N.R. (1985) Nutritional and sensory evaluation of tempeh products made with soybean, ground-nut, and sunflower-seed combinations. Food Nutr. Bull. $7,54-57$.

Viehoever, A. (1940) Edible and poisonous beans of the Lima type (Phaseolus lunatus L.) Comparative study, including other similar beans. Thailand Sci. Bull. 2, 1-99.

Winkler, W.O. (1951) Report on hydrocyanic glucosides. J. Assoc. Offic. Agr. Chem. 34, 541-548.

Yamamoto, H.A. (1989) Hyperammonemia, increased brain neutral and aromatic amino acid levels, and encephalopathy induced by cyanide in mice. Toxicol. and Appl. Pharmacol. 99, 415-420.

Zitnak, A. (1973) Assay methods for hydrocyanic acid in plant tissues and their application in studies of cyanogenic glycosides in Manihot esculenta. In: B. Nestel and R. MacIntyre (Eds.), Chronic cassava toxicity. IDRC (IDRC publ. No. 010e), Ottawa. pp. 89-96. 